\title{
The Utilisation of Africa's Environmental Resources and the Challenges of Globalisation: A Case Study from Eastern Tanzania
}

William Rugumamu*

\begin{abstract}
This paper concerns the micro-environment and globalisation nexus. With the effective participation of the leadership in Morogoro region, Melela village on the leeward side of the Uluguru mountains was identified as an ecologically and economically problem area typified by, among others, periodic drought, crop failure, food shortage and famine, relief food supplies, urban-rural migration, land use conflicts and a community sensitive to agricultural market signals. It is indeed this state of affairs that makes Melela village an interesting diagnostic case that calls for in-depth analysis of agro-biodiversity conditions under economic globalisation and indeed for urgent resource planning and management.
\end{abstract}

\section{Résumé}

Cet article porte sur le réseau du micro-environnement et de la mondialisation. Avec la participation effective des dirigeants de la région de Morogoro, le village de Melela, situé dans les montagnes Uluguru, et placé sous le vent, a été identifié comme une zone posant des problèmes d'ordre écologique et économique, caractérisée entre autres par une sécheresse périodique, des récoltes déficitaires, des pénuries alimentaires, des périodes de famine, l'acheminement d'aide alimentaire, une migration urbaine-rurale, des conflits fonciers et une communauté sensible aux signes du marché agricole. C'est cette situation qui fait que le village de Melela est un cas particulièrement intéressant à étudier, qui appelle une analyse profonde de

\footnotetext{
* University of Dar es Salaam, Tanzania.
} 
l'agro-biodiversité dans le cadre de la mondialisation économique, et exige également une planification ainsi qu'une gestion urgente des ressources.

\section{Background to the Problem}

Sub-Saharan Africa (SSA) is endowed with a rich diversity of environmental resources. Some of these terrestrial and aquatic resources are country specific while others transcend national boundaries of two or more countries within the region. Since World War II, Africans have embarked on the massive utilisation of their environmental resources for improving their quality of life and that of their global business partners (Frobel et al. 1988; French 2000). In spite of the abundance of these resources, local communities, predominantly smallholder farmers and pastoralists, whose production systems are based on traditional environmental knowledge systems (TEKS) are now unable to meet their basic needs, sustain environmental productivity and even have an equitable share of the global wealth (ADALCO 1990). The predominance of international trade over local needs fostered, among other things, specialisation in spatial production and exchange of goods and services on a global scale. As a consequence, it is evident that in some geographical areas, natural resources are still sustainably utilised, while in others there is evidence of environmental degradation (Stebbing 1935; Timberlake 1985; Blaikie 1989; Juma and Ford 1992; Rugumamu 1993; Boyce 2002).

Modern-day advances in agricultural technology in industrialised countries, however, pose great challenges that lead to the failure in the agricultural industry in the subregion. Smallholder farmers cannot afford modern-day environmental knowledge systems (MEKS). With globalisation accelerated by advancement in media technology and communication, these technologies are gradually diffusing universally and are creating an environment for rapid changes in the economy in SSA (Ohiorhenuan 1998; French 2000; Boyce 2002). Being supported by new supranational policy regimes, such as the World Trade Organization (WTO) and the Global Environmental Facility (GEF), trade and production are becoming more homogenous. Under the Structural Adjustment Programmes (SAPs) championed by the World Bank (WB) and the International Monetary Fund (IMF) (Brown and Tiffen 1993) globalisation is pursued in order to facilitate the use of modern-day agricultural production systems to revamp the ailing SSA economies. 
Given that in Tanzania, like in other SSA countries, environmental resources form the corner-stone of socio-economic development, and that the nature and characteristics of the environment are ultimately limiting factors for the well-being of the local people and the state, there is the need to come up with strategies and tools for environmental policy and programme reform in planning land use. For the government of Tanzania, one way of combating ecological and socio-economic depression has been to opt for political and economic reforms under the structural adjustment programmes (SAPs). These policies are tailored around perceptions of the international donors (the International Monetary Fund, the World Bank, United Nations agencies) regarding the causes of and solutions for Africa's underdevelopment (Blaikie 1985; World Bank 1997; Juma and Ford 1991; Rugumamu 1993). Their goal is to create conditions conducive to the play of free market forces and free flow of goods and services between countries and the outside world. (Lal et al. 1988). As noted by Rugumamu (2001) among others, processes of globalisation and their impacts have been documented at the macro-level in a variety of ways. There are however, few corresponding studies at the micro-level.

This paper concerns the micro-environment and globalisation nexus. With the effective participation of the leadership in Morogoro region, Melela village on the leeward side of the Uluguru mountains was identified as an ecologically and economically problem area typified by, among others, periodic drought, crop failure, food shortage and famine, relief food supplies, urban-rural migration, land use conflicts and a community sensitive to agricultural market signals. It is indeed this state of affairs that makes Melela village an interesting diagnostic case that calls for in-depth analysis of agro-biodiversity conditions under economic globalisation and indeed for urgent resource planning and management.

\section{Theoretical Framework}

Globalisation is conceived as a set of worldwide processes which strive to selectively link the world economy into a single global market village. The increased shrinkage of economic distances between and among nations is facilitated by policy changes towards economic liberalisation. The integration processes are also strongly associated with rapid development in technology, production, trade, and finance. They are thus correctly seen as consisting of two separate but not necessarily mutually exclusive trends - the globalisation of production and trade, 
and the globalisation of finance and capital flows. The rapid advancement in the field of information communication technology (ICT) set in motion by transnational corporations (TNCs) and other actors has facilitated linkages across national boundaries. The processes have since opened new gaps between information-rich industrialised nations and information-poor developing countries. Some actors in the game, mostly in the North, gain whilst the majority of those in the South lose (Kennes 1997; Hoffmaister et.al 1998).

The TNCs and other actors are a lead agency in the allocation and re-location of national economic processes within a global system. TNCs are more able to control and hence link national level companies and markets to international ones (Boyce 2002). Conventionally, these linkages have accelerated the integration of two spatio-economic systems, namely a globalised space in the developing countries, and a globalising space at the centre of the global economic system in developed countries into one whole (Milton Santos, pers. com; Amin 1976.). The polarisation of technology at the centre through massive investment in the telecommunication and computer systems for networking and online data distribution by satellites is a process that makes areas and distances shrink, making the centre the custodian of technology and power and hence the engine for global unilateral change.

On the policy side, one instrument for global trade integration is the creation of the WTO. The establishment of this institution has ushered in a new era of multilateral trading arrangements. Within this framework, however, SSA economic performance between the mid-1980s and the 1990s has been disappointing (UNCTAD 1993). It is reported that SSA economies experienced falling shares, mainly relative to other developing countries, during 1987-91 in spite of preferential market access accorded to them. This demonstrates how Africa has failed to economically compete on the global scene. These results may be attributed in part to the inability of Africa to assert herself in the fields of trade, technology, finance and production in a global village.

Centres in the globalised space, the periphery, serve as facilitators and consolidators of technology and power from the western centres, but not vice-versa. The impacts of the total processes on a globalised space might be reflected by the degree of environmental degradation and economic decline. Furthermore, the dynamic relationships in the global system will serve as an indicator of the behaviour of the key role players with respect to environmental resources. It is within this frame- 
work that a better understanding can be gained at the micro-level of the mechanisms necessary for regulating sustainable resources productivity under economic globalisation for present and future generations in the subregion.

The environmental resource component considered in this study is land. Geographically, the concept land refers to a specific area of the earth's surface; its characteristics embrace all reasonably stable or predictably cyclic attributes of the biosphere vertically above and below this area including those of the atmosphere, the soil and the underlying geology, the hydrology and the plant and animal populations, and the results of past and present human activity, to the extent that these attributes exert a significant influence on present and future uses of the land by humans (adapted from Smyth 1972; FAO 1976). Included also are the adverse results of human activity processes. The principle objective in land resource utilisation that this paper seeks to promote is the attainment of sustainable economic development and social equity through the wise utilisation of the resource base for the present and future generations (WCED 1987).

Sustainability and development as concepts have had a variety of interpretations since they gained prominence in development literature in the 1980s. The World Commission on Environment and Development (WCED 1987), for instance, refers to 'development that meets the needs of the present generation without compromising the ability of the future generations to meet their own needs' as sustainable. Unfortunately, a focus on sustainable development has diverted attention from gross inequities that exist between and among the people of the South and North. Furthermore, it has glossed over the disproportionate use of power and resources within and between the North and the South. Sustainability in agriculture and natural resources should thus allow for progression towards an ever improving quality of life - for nations as well as individuals and the environment (The Independent Commission on Population and Quality of Life 1996). It is against this background that the article conceives sustainability as a strategy that consolidates environmental and developmental concerns in pursuance of economic prosperity and social equity while preserving the integrity of Mother Nature for future generations.

To this end, sustainable productivity of the land user and the environmental resource base in the SSA is conceptualised at a production unit level within a specific macro-ecological zone. When the agricultural 
production goals are dictated by needs of the community, and the resilience of the resource base is maintained indefinitely, then the pattern is sustainable. As the production process is linked to the needs of the North and indeed at the expense of the survival economy, an overutilisation of natural resources which exacerbates degradation is inevitable. For this very reason it is timely to explicate the impacts of the land users' economic activity processes and their technology on the productivity of environmental resources within global market forces.

Technology, as an engine of development, may be broadly conceptualised as systematic knowledge, skills, practices and machines, usually of industrial processes but applicable to any recurrent activity process. Being closely related to science and engineering, technology deals with the tools, skills and techniques for carrying out the plans (Muller 1980) through liquidation or consolidation in industrial technology. As reported by Chungu and Mandara (1994), technological development is important as a major determinant of the level and pattern of national economic development and also as a major determinant of international competitiveness. Economic development and technological advancement are positively correlated.

It is in this light that the sustainability of agricultural production and the physical environment should be seen (Cooke 1991). This is central in development, in that it is conceptualised at the outset that we are concerned at all levels - household, local, sub-national, national and international (Carpenter 1980; Blaikie 1989; Boyce 2002). As globalisation strives selectively to integrate the world into a single global market village, the prospects for sustainable development of ecologically and economically marginal areas have to be clearly understood. It is within this framework that this article contributes to a critical assessment of the impact of processes of economic globalisation on the utilisation of Africa's environmental resources.

\section{Objectives and Methodology}

The specific objectives of the article are two-fold. First, to assess the impacts of economic globalisation on the environment with specific reference to an ecologically and economically fragile ecosystem typified by Melela village in eastern Tanzania. Second, to propose a viable approach for achieving socioeconomic prosperity and equity and ecological stability through community-based resource use systems in Africa. 
To achieve these objectives the paper adopts a methodology based on a political economy approach in understanding the application of ecological principles in agricultural production processes under economic globalisation. The issues examined are the contemporary socio-economic ecological relations of smallholder farmers to their land holdings as well as with their business partners. The approach thus seeks to integrate local human needs and ecosystem production capacity within an international economic setting as a basis for identifying adverse consequences and a search for sustainable development. The paper draws evidence from the study of an area on the leeward side of the Uluguru Mountains in Eastern Tanzania. This approach therefore, pays equal attention to the local communities' livelihood needs and those of the ecosystem, plus the generation of a surplus for the international market by providing a holistic framework for sustenance in the realm of environment, economy and policy development.

The remaining part of the paper falls into two main sections. The proceeding part outlines contemporary land use types and environmental management technologies, both traditional and modern ones, as a basis for a better understanding of relationships between economic globalisation and the utilisation of environmental resources. The section thereafter reviews the key impacts of economic globalisation processes on environmentally and socioeconomically marginal ecosystems in SSA as reflected in Melela village in eastern Tanzania.

\section{Assessment of the Environment and Economy in Eastern Tanzania under Globalisation}

Farmers' land holdings are a component of a specific macro-ecological zone, the semi-arid zone. The discussion considers the agrobiodiversity conditions for the functioning of a given farming system. It explores contemporary land use types and environmental management technologies, both traditional and modern, as a basis for a better understanding of relationships between economic globalisation and the utilisation of environmental resources.

\section{Evolution of the Utilisation of Tanzania's Environmental Resources}

Experience in the SSA countries reveals a long tradition of well-adapted TEKS for sustained environmental productivity before the coming of 
colonialism (Ruthenberg 1971; Van de Welle 1972; Kjekshus 1977; Rodney 1980; Neriove 1988). Allan (1965) notes, for instance, that pastoralists were capable of assessing the feed value of different rangelands and their stock carrying capacity at different seasons of the year. The Barabaig in northern Tanzania have a strong stake in maintaining fodder trees and have customary rules regarding utilisation. Amongst the agropastoralists, there were some communities who developed a sustainable agricultural production system based on mixing crop production with animal husbandry, until the arrival of Rinderpest (Kjekshus 1977).

With respect to the skills and innovativeness of the land users, Boserup (1965) cites the case of Ukerewe Island, in Lake Victoria, where population pressure has triggered agricultural intensification through technological inventions, thus averting food shortages and maintaining soil productivity. Further more, the ability of the farmers to adopt new crops such as rice and maize in the nineteenth century and to incorporate them successfully in their farming systems (Illife 1972) is a positive indicator of the farmers' ingenuity in sound land husbandry. It is further reported that during the pre-colonial period, the Sukuma people, south of Lake Victoria, had already developed mechanical soil conservation technology (Rounce and Thornton 1939). The farmers construct tie-ridges to address the problem of soil-water loss, fertility depletion and decreased yields.

In spite of these technological and institutional advances in earlier times, land degradation processes are as severe as ever (UNSO 1986; Hudson 1987). In some areas, the problem has since been associated with drought hazards, when in actual fact, drought is one of the precursors (Rugumamu 1993). Recent studies have revealed that land degradation in Tanzania knows no ecological boundaries (Rapp et al. 1973; Amin 1986; GEO-SAREC 1990).

It has been noted that in the semi-arid areas of Tanzania only poorly vegetated areas are susceptible to surface run-off as downpours set in (Van Rensburg 1955); Christiansson 1988). Such a monolithic view of the problem has led some distinguished scholars to refer to soil erosion as a technical issue (Morgan 1986; Stallings 1987). They propagate terracing, gully stabilisation, tree planting and so on as control measures, when in essence the problem is socio-economic, political, ecological and technological in origin. This is a holistic view of environmental degradation propagated among others by Carpenter (1980); Blaikie 
(1985); Feierman (1990); Shiva (1991); Juma and Ford (1992); Rugumamu (1996); Boyce 2002).

The failure of colonial policies and measures to combat ecological degradation in Tanzania is clear testimony of the lack of a holistic approach to mitigate the hazard. For instance, most efforts directed to export crop production improvement have had no bearing on either food crops, livestock keeping, forestry nor water sources management, reflecting a high level of sectoral fragmentation. According to Berry and Townshend (1973), the colonial administrators failed to take into account the land users' attitudes to conservation when prescribing conservation measures. It is argued here that the land users were not involved in planning land management. It is the local skills and practices employed by smallholder farmers that are the major foundation for sustaining agriculture and the environment (Biowman 1974; Hudson 1987; Feierman 1990; Choucri 1998). Hence the colonial commandtype approach to environmental management created resentment among smallholder farmers and pastoralists which in turn endangered resource sustainability.

In response to declining land productivity, the Government of Tanzania has introduced a number of programmes and policies since independence, but has met with limited success (Berry and Townshend 1973; McAuslan 1980, DANIDA 1989; Rugumamu 1996). It is imperative, therefore, to assess the impact of globalisation on the environment and development.

\section{The Case of Melela Village, Uluguru Mountains in Eastern Tanzania}

This subsection outlines the environmental resource base with which economic globalisation articulates. The tract of land of the Uluguru Mountains referred to is the leeward side represented by Melela village settlement (Rugumamu 2000). The village is located about $35 \mathrm{~km}$ in the neighbourhood of Morogoro municipality and along the TanzaniaZambia Highway (TANZAM). The size of the village is yet to be accurately determined but official estimates put it at 80 square kilometres (8000 hectares). Administratively, the village is a subset of Mlali ward, Morogoro Rural district in Morogoro region, Eastern Tanzania. The 
region is one of the 20 administrative regions in Tanzania, and occupies about 8.2 percent of the total mainland area.

As for local level governance, Melela is governed by the village council and headed by a democratically elected chairman. There is also a village executive officer who is a local government employee. The secretary and the various village committees, finance and planning, social services, and defense and security issues, are the council's executive arms as provided for in the 1982 Decentralisation Act. Administratively, the village is subdivided into nine sub-villages (vitongoji) each led by a ten-cell entity (balozi).

Geologically the country rock in Tanzania is composed of the PreCambrian basement complex that has been subjected to tectonic and metamorphic processes and cycles of erosion resulting in a mosaic of rock types and landforms (Berry 1971). Geomorphologically the Uluguru mountains, of which the Melela is but a part, have been subjected to block faulting in several orogenic periods during the late Tertiary, Pleistocene and as recently as the Holocene. The occurrence of small inselbergs in this unit spells a multiplicity of land facets namely the hillcrests, upperslopes, midslopes and footslopes. V-shaped valleys and tributary channels with steep sloped sides dissect this pediment, and ephemeral streams characterise the study village during the short and long rainy seasons as uncontrolled surface runoff. Permanent rivers include the Melera and Kikundi and some of their tributaries.

The mountains intercept the South East Trade Winds (SETW), thereby creating a rainshadow over the village. It is this environmental condition that is typified by a fragile semi-arid type of climate, given that climate is the most important single factor influencing agricultural production in SSA. The annual average amount of rainfall at the Melela site in the rain shadow is $719 \mathrm{~mm}$ (Jackson 197 I). Further, the amount of rainfall tends to increase significantly with increasing altitude reflecting marked precipitation variation within short distances around the mountainous land surface (about $0.2 \mathrm{~km}$ ). On the temporal scale, rainfall distribution on the leeward side starts in late February and continues into early May. It peaks in March and April, occasionally accompanied by violent thunderstorms. Generally, short rains are atypical yet in good years they are reported by farmers to start in late October and end in early December. The dry season lasts for up to nine months and starts in early June and ends in mid-February. 
Using a $51 \mathrm{~mm}$ month as a criterion for assessing the length of a rainy season (Jackson 1971) the village experiences a soil-water deficit for almost the whole year round, punctuated by a short growing period of about 90 days. Furthermore, the village experiences periodic drought (occurring every four to ten years). The PRA team reconstructed 1974, 1978, 1984, 1988 and 1998 as a series of dry years with disastrous effect on the crops, livestock, and water sources. This condition renders the village vulnerable to the serious effects of drought, a precursor of desertification. A dependable rainfall occurs in one out of five years. Most dependable water sources for human development in the study area include traditional boreholes, popular shallow wells (mdundiko), and piped gravity water from the slopes of the Uluguru Mountains.

The mean annual temperature and evaporation are $23.40 \mathrm{C}$ and $1760 \mathrm{~mm}$ respectively. It is noted that the annual temperature range (5.40 C) is generally less than half the monthly range. Seasonal temperature variations are small, and the diurnal range is more significant given pronounced temperature inversions in the deep mountain valleys at night. The leeward village location influences day length, wavelength and the intensity of light. All these aspects are important factors, especially with regard to plants, as they do not vary independently. It should be noted that as the mean angle of incidence becomes more oblique, it affects the intensity of different wavelengths to different degrees to the extent of the convex slopes being left in the shade. It should be noted that both temperature and sunlight have marked effects on growth and development of plants and indeed crops - the processes decreasing as the two variables decrease.

After rainfall, probably the single most determining influence on agricultural production is soil conditions. Soil is thus a major resource for human development, especially in developing countries. Melela soilscapes may be grouped into three types, namely the skeletal soils (Lithosols); the moderately deep and excessively drained soils, and the well to imperfectly drained deep soils. The latter two types may be tentatively classified as Ferralsols varying from Rhodic to Ochric. The skeletal soils are shallow (less than $25 \mathrm{~cm}$ deep),derived from acid gneisses. These soilscapes are dark reddish brown sandy loams typical of hillcrests and upperslopes. The moderately deep and excessively drained soils (25-100 cm deep) are derived from in-situ, weathered and colluvial materials occupy steepslopes. They are yellowish brown sandy clay loams to well drained yellowish red clay loams and stony silt loams. 
These soilscapes cover most of the upper piedmont land unit, typified by upperslopes and midslopes. The well to imperfectly drained deep soils are derived from colluvial-alluvial materials found on the lower pediment on gently sloping to relatively flat footslopes. These soils are predominantly dark grayish brown silt loams to yellowish red sandy clays and clay loams. Mineralogical analysis reveals high kaolinitic clay content (30 percent) found in the lower pediment land unit soils which makes them suitable for brick making (both sun-baked and kiln burned bricks).

The selected community is typified as practising low-external-input systems - TEKS. A horticultural centre locally known as Melela Bustani, a private farm enterprise within the village ecosystem, was identified as a model for natural resources management for sustainable development based on MEKS. This foreign managed farm is a highly mechanised enterprise that could serve as the vision for Melela community and the entire lee-ward Uluguru mountain ecosystem on the biospheric part of production conditions, but of course, not on the economic front. The two production systems have been reported to have good relation in the context of exchange of some aspects of technology and markets.

This sample area is floristically poor and dominated by shorter degraded woodland, the eastern miombo type. The upper pediment is typified by much shorter Brachystegia boehmii, B. speciformis, B bussei and Julbernardia globiflora to degraded Combretum bushland in the dry areas. These trees are mixed with grasses like Hyparrhenia rufa and Panicum maximum as understorey. The lower pediment's native vegetation is dominated by the Acacia-Comiphora deciduous woodland/ bushland and Hyperrhenia spp in the wetter areas. While some hillcrests are denuded others are covered by medium Heterogon-Combretum wooded grassland. Vegetation has been severely degraded by human processes, and the current threats include housing construction, cultivation, grazing, fuel wood, bush firing, accelerated soil erosion, urbanrural migration, and weak regulatory by-laws. The productivity of the land resources in this ecosystem is, therefore, facing the risk of overexploitation.

In terms of land use, agriculture is the most important socioeconomic activity in this rural setting. In 1999 it was estimated that about 38 percent of the arable land was under cultivation with the rest of the village land lying fallow and/or serving as pasture. Based on ecological conditions and recently on dietary preferences coupled with develop- 
ments in agritechnology, the staple food crops grown include maize, sorghum, and millet. Minor crops are legumes, vegetables, and fruits. National campaigns on food security have facilitated the substitution of drought tolerant crops like serena and lulu for sorghum, and staha, kilima, and katumani for maize. Agricultural production is predominantly subsistence farming and livestock raising. Farming practices employed by the majority of smallholder farmers are characterised by short fallow periods, rudimentary tools including fire for bush clearing, and the generation of a cheap soil ameliorant such as crop residues and ash. The village authorities consider both wildlife, vermin and livestock to be natural enemies of the agricultural industry.

As for the livestock keeping, indigenous breeds of cattle, goats and sheep define the industry in the study area and in Tanzania in general. Other domestic stock includes pigs, donkeys, and chicks. The livestock population, save for pigs and chicks, is raised by way of the transhumance system. It is normally the lactating and the sick stock that depend on the village pastureland. The Masai and Kwavi are the main livestock keeping community. They are either agropastoralist or pastoralists keeping large numbers of stock and tilling the land. The pastoralists advance that seasonal migration and burning of rangeland during the dry season are strategies for pasture resource management.

Afforestation activities are ongoing in the area as can be witnessed around some homesteads, dispensaries, primary schools, and village offices (formerly godown). The most renowned development partners in this field include HOCEDSO - a Finnish NGO, World Vision and Catholic Integrated Community - a German-supported NGO, and locally known as Melela Bustani. These institutions have set up tree nurseries, promoted tree-planting education through competitions and with the school. The current tree planting campaign championed by NGOs, among other initiatives, appears to be a positive move towards greening the environment.

Waluguru people mainly inhabit the village with a minority of Wakaguru, Wakwavi, Wamasai and Wachaga. The village leaders estimated the village population in November 1999 (just before the 2000 general elections) as 3364. The able-bodied men and women resident in the village were about 1960 of whom around 51 percent were women. The average household size was five persons. As regards the origin of households, about 53 percent of the interviewees (52 heads of households) were born in the village, 11 percent within Mlali ward, 
14 percent within Morogoro rural district, and 21 percent migrated into the village from outside the district. The survey shows that the village population growth is greatly influenced by immigration among other determinants. The Melela community also confirmed that the factor contributing most to population change was in-migration, especially urban-rural movement.

According to the sample, the population quality was such that slightly less than half of the women interviewed had no formal education compared to only about one-fifth of the male population. It clearly demonstrates that men have greater educational opportunities than women, even in the rural areas. The study, however, showed a high illiteracy rate. Traditionally, many parents do not consider sending their daughters to school on the grounds that they should help mothers with domestic and farming activities (Headteacher, pers. com). Education, as one of the most important factors in development and the one on which advances in health, wealth-creation and political culture and technology depend, is central to ecological sustainability. There was a deliberate attempt at involving a young group since it possesses the potential for sociocultural change. About 41 percent of the sample (42 respondents) constituted the aged with 55 percent being men, while the rest were youths, with 65 percent women and 35 percent men. The following subsection explicates key contemporary environmental utilisation types in Melela village.

\section{Characterisation and Assessment of Major Land Use Types}

Based on the adaptation of the FAO (1983) approach, five land use types were identified as a basis for characterising and evaluating Melela village land and the uses to which it may be put. The analysis of the two variables was based on the site and socio-economic conditions within which the industry operates. It is worth emphasising here that more than one land use may be practised in one enterprise, though not in one spatial continuum. The major land use types are:

Al: Smallholder rain-fed arable farming and improved traditional technology based on crop mixture of millet/sorghum/maize/cassava combined with legumes (beans, pigeon peas) with or without livestock.

A2: Smallholder rain-fed arable farming and improved traditional technology based on rice and sugarcane. 
A3: Smallholder rain-fed arable farming and intermediate technology based on maize, (cotton and sunflower - dropped), vegetables with or without livestock.

L1: Smallholder livestock keeping and improved traditional breeds, namely cattle, goats, sheep, donkeys, and poultry, all based on ranges (agropastoralism).

L2: Smallholder livestock production based on improved traditional pig farming.

\section{Setting and Produce}

The land users' ingenuity and diligence with which they have managed their natural resources through time may be seen across the current resource use patterns over time and space. Generally, the land users have been able to locate and reallocate specific land use types in particular sites on the landscape, a catenary sequence (Conacher and Darlymple, 1977) for particular time periods with very limited agricultural extension support. The stakeholders subdivide their village land into three main units. These are Kilimani (Upslope), Mteremko (Midslope) and Bondeni (Footslope). This feature is as evident in the distribution of crops in the study area as it is in the siting of particular land use types on specific land units or otherwise over time.

Land use Al characterised by millet and/or sorghum and/or cassava and/or maize combined with legumes is the most common land use type on almost all land units in the study area except where physical land resource limitations such as severe erosion sites, steep slopes, very shallow soil depths, or waterlogging occur. Land use A2 typifies monoculture crops and although rice is grown as both a lowland and upland crop, sugarcane is mainly a lowland one. The PRA team was aware of the concept of limitations on land use type to command location as a social construct, and hence the decision whether or not to use a soil resource was subject to debate.

Land use A3 constituting maize, non-food commercial crops (formerly cotton and sunflowers), was typical of the well drained level to gently sloping land facets on the lower pediment's footslope. Small holders explained that, due to poor marketing systems (a combination of the Tanzania Cotton Authority [TCA], National Milling Corporation $[\mathrm{NMC}]$ and the private sector), the production of cotton and sunflower has been abandoned in favour of maize. This land utilisation type reflects the smallholder farmers' sensitivity to market forces and the Regional and District Authorities' concern to reintroduce the pro- 
duction systems and regain foreign exchange earnings. This state of affairs reflects the effects of globalisation. Authorities are working hard for the reintroduction of non-food commercial crops, and the situation involves the reorganisation of space by forces external to the land tiller and also to itself.

In the recent past (1960s), land use $\mathrm{Ll}$, including $\mathrm{Al}$, A2, A3 practising livestock keeping, were commonplace on almost all leeward side members of the catena on a seasonal basis. Basically cattle, goats and sheep rely on natural pasture under free range. Every respondent who owned livestock was of the opinion that there was not enough grazing land. The dry season is characterised by an acute shortage of pasture and water. The distance to grazing land varies between the wet and the dry seasons. During the latter season animals wander longer distances looking for grass. As a general pattern, dry season grazing is carried out in the surrounding swampy plain and beyond. During the short wet season, livestock grazing is conducted around village land, especially on the short fallow land, on the stubble, and on forest land. This freerange management type opens almost all of the landscape units to $\mathrm{Ll}$, albeit on a rotational basis with crops and other uses of the land over time. The issue of mobility of this land use type Ll has a critical bearing on resource stewardship and conservation and the quality of life of the land users on a national scale. These agropastoralists/pastoralists have been trekking the country in search of grazing. Sedentary peasants tend to act as barriers and by the same token intensify resource use under traditional management systems. Incidentally, some herdsmen tend to deliberately graze their stock on farmers' crops, a situation that triggers conflict. The issue of conflict disaster, currently a hot debate in Tanzania, needs to be taken up in a full study.

Land use L2, typified by pig production under improved management, is carried out in the compounds of progressive farmers with zero grazing. The produce from this land use type is both pork and live animals. All pig farmers interviewed (14 percent) construct pens made out timber, and mostly feed their stock with maize husks. Distance from the farmers' dwellings is greatly influenced by the level of the security of the stock (an average of between 8 and 10 metres from the residential house). This land use type is, therefore, site specific. 


\section{Farm Holdings}

Farm holdings are composed of disaggregated small plots. These small plots without specific geometrical shape appear to be located haphazardly on the land surface. The survey revealed that an average household farm size is an aggregation of small plots of about $1.4-3.8$ ha in size. The available family labour and financial resources are major constraints on the size of farms. The largest farm in the sample was 15 hectares. Given an average household size of 5 members, this is indeed higher than the estimated national cropland available per capital of 0.3ha in 1990, which was expected to drop to 0.005 ha by 2025 (UNDP 1999).

By way of summary, for Land use A1, A2 and A3 it was found that out of 98 sample interviewees, about 19 percent cultivated less than one hectare, nearly half ( 48 percent) hoed one to two hectares, about 20 percent ploughed between 2.1 and 5.0 hectares, while 10 percent cultivate between 5.1 and 8.0. The remaining 3 percent cultivate more than eight hectares per year. With respect to the tenurial issue, it has been noted that its general nature has been changing in Tanzania since independence in 1961, as reviewed in the National Land Policy (Ministry of Lands, Housing and Urban Development 1995). The most conspicuous feature was the conversion of freehold titles to leaseholds under the Freehold Titles (Conversion) and Government Lease Act (Cap. 523) of 1963. This system was later changed into Rights of Occupancy under the Government Leaseholds. These changes lead to a decline in customary rights and the abolition of landlord-tenant relationships (Shivji 1998). These and other developments, notes Shivji (1998), have culminated in state land ownership and control. In Melela village, the village government holds land. Individual farmers have usufruct rights.

Land use Ll was being practised by eight percent of the sample. Livestock ownership ranged from one to fifty for two respondents, fifty one to two hundred for two respondents, two hundred and fifty one to five hundred for three and more than five hundred head of livestock for only one farmer. As for grazing land at the village level (land use Ll), pasturelands are communally owned. But further out from Melela village the land belongs to the state and there is no formal control of grazing. With a change in economic policy, land which apparently had no market value is now a scarce resource. This new economic environment calls for an attendant policy shift toward a marketisation system 
that looks after the conventional livelihoods of the majority of the rural poor while simultaneously promoting private sector development. The current situation is perpetuated by the parallel nature of traditional and modern laws - hence casting a shadow on access to and control over resources, a prerequisite for tenure security and sustainable resource utilisation cum conservancy (Rugumamu 2000b).

Weather changes, both seasonal and aperiodic, affect the availability of and hence distance to both pasture and drinking water points. The main sources of drinking water for animals and people are springs, rivers, and ponds (mabwawa). It was found out that estimated distances to water points for land use Ll varied from less than ten kilometers within the village boundary during the rainy season, to more than ten kilometers away from the village, ward, district, region, and even across the international borders to the southern neighbouring states.

Land use L2 employs zero grazing techniques in the raising of pigs. The main fodder is maize husks. All farmers in this category store the fodder to last for six to nine months, the life cycle of the stock. It was noted that at village level this feed supply faces stiff competition, with local brewing demand creating shortages, especially during the crop planting season when the cereals are in short supply.

With respect to land use $\mathrm{Al}, \mathrm{A} 2$ and $\mathrm{A} 3$, the sample respondents stated that the tenure systems included inheritance (70 percent), village government allocation ( 11 percent), self acquisition ( 5 percent), and renting ( 12 percent). In some circumstances land may also be bought (2 percent). Land use types $\mathrm{Al}, \mathrm{A} 2, \mathrm{~A} 3$ are characterised by individual (private) ownership of plots under the head of a household. Amongst the Waluguru, the women inherit land, and when they marry their husbands live on the inherited land. A decision on how each parcel is to be used is made by the husband, the head of the household. Usually women have access to household land if part of it has been left uncultivated. The women may put this land under minor crops such as legumes. For rich female farmers some plots may be loaned out to the needy and even sold to other farmers.

At village level, transport is predominantly non-motorised - that is, human muscle. A few farmers own bicycles (14 percent) and others ( 8 percent) use tractors to transport crops (maize) from the fields to the homestead. In all land use types crop and livestock processing, transport is by traditional technology, thus making demands for mechanisation very low. 
In an effort to understand the relationship between farm size, access to land and basic needs, it was found that 98 percent of the respondents felt there was enough land, and 20 percent stated that they could not meet their aspirations from the existing land resource base. Given that each farmer normally cultivates more than one plot, and these plots are randomly distributed along the village soilscapes, it is not surprising that in view of the system of land control, more women's plots than male ones are to be found on poorly productive sites. Being less productive, women's plots are also susceptible to degradation over time as they are put to use.

\section{Household gender division of labour}

The present gender division of labour at the household level is predominantly a reflection of the colonial capitalist mode of production (Rodney 1980). Generally men, women and children work on the farm and take care of the livestock with some degree of specialisation (Little 1991; Rugumamu 1999). Over and above these activities, women, with the assistance of children, are responsible for all the domestic chores. At the end of the day, women are more involved in food preparation and cash crops as well as livestock production processes than men.

\section{Market orientation}

Agriculture in the semi-arid areas is characteristically subsistence oriented (Rugumamu 1996). Regarding land use type Al, food crops are sold and bought within the village markets. The favourite staple food, maize, is also a cash crop which may be sold soon after harvest and rebought just before the next sowing season as household food reserves run down. Before economic liberalisation, that is pre-SAPs, maize was sold to the state organisation, the NMC. Thereafter, the crop has enjoyed an assured market in spite of institutional malfunctioning. The findings reveal that, first, state marketing institutions (e.g. NMC, TCA) failed to buy their crops in good time, and even worse have underpaid for them. Now, under market-driven globalisation, the farmers have completely lost the usual outlets for their traditional cash crops. The present free market system has introduced the village market to unreliable crop buyers including consumer co-operative societies, saving and credit societies, and private entrepreneurs. The field findings show that the government has almost always left the peasants in the hands of 
businessmen under the umbrella of economic liberalisation. Following from this the farmers have dropped the production of traditional export crops, like cotton and sunflowers, and intensified the production of the ecologically delicate commodity of maize, which enjoys demand in local, national and international free markets.

Land use type LI produces dairy products and meat for domestic use and live animals, as well as hides and skins for local and international markets. Livestock are also a source of farm manure for the few progressive farmers. As for land use L2, farmers sell live animals and on very rare occasion's they sell pork. The latter is due to lack of local market as pork is more expensive and indeed a wild variety can be freely obtained in the bush. There is a growing pig market in Morogoro Municipality as well as in Dar es Salaam.

In terms of socio-economics, livestock, given their mobility, serve as security against droughts that destroy crops, and also against famine (animals can be exchanged for cereals). To the Masai and Kwavi agropastoralists livestock keeping is a cultural practice tied to their livelihoods unlike in a modern market system. A formal market for livestock products was also not evident. This applies to the lack of the livestock industry's infrastructure such as cattle routes, market posts, and security. At community level livestock are also needed in order to perform traditional ceremonies. It is against this background that the agropastoralists prefer to keep 'large' herds and are reluctant to reduce their stocks when pasture demand exceeds supply in a particular area. This state of affairs exacerbates transhumance and its negative environmental consequences. Some cultural attitudes and values, therefore, tend to propagate negative effects on commercialisation processes and on the environment. It is hence unquestionable that realistic price mechanisms coupled with environmental education and communication will encourage the agropastoralists to invest part of the profits in their land in order to raise its productivity.

Following from the above observation, it may be stated that the need for stabilising market development in the local economy cannot be overemphasised. It is therefore in this light that the lack of pro-poor investment in the natural resource base should also be seen. 


\section{Key Impacts of Globalisation on Environmental and Socio-economic Sustainability}

Here an attempt is made to review some key impacts of economic globalisation processes on ecologically and socioeconomically marginal ecosystems in SSA as reflected in Melela village in eastern Tanzania. Carson (1962) was one of the first writers who eloquently articulated the issue of ecological degradation due to human mismanagement of the environment. The current economic liberalisation programmes regarding investment in agriculture can be considered in this light (Amin 1976; Seidman and Anang 1992; Brown and Tiffen 1993). For analysis, the paper draws heavily from available evidence in the semi-arid areas of Tanzania and indeed elsewhere, where most smallholders use low level technology in their production, storage and environmental conservation activity as a survival strategy. Experience, however, reveals that the world over farmers carry out 'experiments' on their farms, and adapt, innovate and observe the results of their efforts in manipulating these artificial ecosystems. Creating knowledge in this way is hence an integral part of sustaining ecological and agricultural productivity in the SSA (Rugumamu 1993). It may be advanced on the outset that intensive human use of fragile ecosystems is a risky investment both economically and ecologically.

To this end, it is anticipated that economic globalisation processes and their ecological-economic impacts may be understood through examining (i) financial investment by transnationals (ii) the growth of manufacturing of high technology machineries, seeds, fertilizers and insecticides, and (iii) the marketing of technology and produce.

\section{Financial investment by transnationals}

Private companies and financial institutions at the centre of developed countries are the agents of financial investments in developing countries under the banner of liberalisation of the global economy. Some urban entrepreneurs supported by foreign investors such as TNCs form major corporations investing in the high-value commodities in the agricultural sector (Barraclough and Finger-Stich 1996). WTO, for instance, is championing such a course. Agricultural land use types being contemplated in this area include smallholder intermediate level technology based on cotton, sunflowers and tobacco. 
Being very influential, TNCs obtain preferential access to public or private lands, water, credits, markets, tax holidays, subsidies, foreign exchange and technology. Further application of low environmental standards resulting, among other factors, from faulty environmental impact evaluations, would exacerbate environmental degradation problems. The high returns in convertible foreign currency from high-value crops such as tropical vegetables and fruits make it an industry which has been greatly favoured by governments in developing countries as well as by transnational banks. Given the above circumstances, the state is compelled to transform multiple use/multiple user resources, historically used by local communities, to single use private property owned by national and/or transnational business corporations. Such circumstances might result in inefficient and unplanned use of environmental resources. As the tracts of land are appropriated by transnationals, the local communities become environmental refugees. But who benefits and who pays the cost of those foreign exchange earnings?

The interplay of foreign capital with local natural resources may be rated as the initial process in the internationally organised vertical integration of the modern-day farming industry within the framework of globalisation and liberalisation processes. National bureaucracies exerting state power too often promote the investment process, thereby aggravating spatial inequality. This process goes hand in glove with industrialisation in developed countries, deepening and widening the economic gap between the North and the South.

This trend has been observed in the study area, where a large tract of land has been set aside for ranching and game farming for an investor. The result has been the concentration of livestock keepers in relatively smaller loci, which in turn has led to pastoralists competing with smallholder farmers and investors for the shrinking land. The outcome is intensification of land use and subsequent soil erosion, sedimentation, and soil mining. Further more, competition for land is resulting in sporadic conflicts and civil strife in the area.

\section{The growth of manufacturing of high technology equipment, seeds and fertilizers and insecticides}

As already noted for the early 1980s, high technology machinery, seed, fertilizer and insecticide manufacturing industries in the industrialised countries of Europe, North America and Asia are likely to become increasingly important due to the rapid demand for agricultural produce 
from the subregion with the onset of massive investment. Furthermore, growth in development research at the centre is prominenbt. An influx of a variety of manufactured inputs including heavy and light farm machinery, genetic engineering (seed), fertilizers, pesticides, herbicides, and veterinary drugs as well as of technical tools for farm management is imminent. The list may also consist of off-farm, post-harvest production links such as industries for further transforming the produce.

The input manufacturers, being price determinants of their goods and services, have over time increased their own profits from developing countries. This is facilitated by the liberalisation policy adopted by most developing countries today. However, it should be noted that a few TNCs increasingly have oligopolistic control over the technology production sector. It follows, therefore, that massive investment will witness an economic boom in the North through industrial growth triggered by the input demand in the South.

In the South, however, organic farming processes carried out by smallholder farmers that are environmentally friendly are being promoted by NGOs. The pressure of foreign demands coupled with the basic family survival needs is suffocating these initiatives. It is in this context that government policies on agriculture that are export-oriented and directed towards earning foreign exchange favour wealthy farmers at the expense of poor peasants who have no access to credit, new technologies and indeed markets. Ultimately, these policies are threatening agricultural sustainability and environmental stability.

In the study area, the high prices for inputs such as fertilisers and insecticides have forced the smallholder farmers to stop production. These economically sensitive land users under the SAP have failed to gain any benefit as the prices of inputs in the absence of subsidies coupled with currency devaluation raises the prices of imported goods. Because there is practically no land use type that cannot be sustainably carried out without the renewal of soil nutrients, the current uses of land are leading to ecological degradation and the intensification of poverty. On the other hand, agricultural development based on subsidy input may lead to overutilisation of non-renewable energy that might result in 'dust bowls' or desertification. In this regard environmental degradation is a function of agricultural land use, the level of technology notwithstanding. 
The above operations link natural resources utilisation in developing countries with industries in developed countries, demonstrating yet another globalisation process referred to here as marketing.

\section{Marketing of technology and produce}

The operations involved in the marketing process include the export of farm products and the import of crop and livestock production technologies. Overseas marketing agents, who are also increasingly powerful actors in the production chain, conduct the process. In several developing countries, it is reported that these providers of inputs such as freezing facilities managed to push direct producers to expand and intensify their production.

It is worth noting at this juncture that these foreign marketing agents tend to have more stable incomes because they often enjoy significant market shares covering almost all countries. Based on the above exposition, it may be stated that there is a general tendency towards vertical integration of the production chain, with TNCs as providers of technology, inputs and credits increasingly controlling all stages from production to marketing in both North and South alike. In the study area the marketing system was liberalised in response to SAPs, with insufficient preparedness planning. This state of affairs has led to weak competition amongst state-owned and private marketing institutions such as NMC and TCA that have failed to buy the export crops in good time, and have underpaid the land users.

In general, the new millennium should signal a paradigm shift 'from always-renewable Nature to revolt against over-exploitation of its resources' (Report of Independent Commission on Population and Quality of Life, 1996). That Mother Nature is finite should not be questioned by modern day biotechnology. Agricultural investment projects, for instance, virtually appear economically viable and environmentally sustainable in the light of MEKs advancement. This view is more challenging now than ever before when the SSA is grappling with the debt crisis that has paralysed to a high degree the social sector (education, health, transport and communication infrastructure) (Adams 1991). The motive driving the investor, however, is the high profitability of the industry and not its sustainability. It should be emphasised that the SSA is duty bound to guard against bankrupting the environmental resources of the future generations who are privileged to benefit most from the work we do today. 
Transnationals argue, for instance, that investment projects in developing countries create employment opportunities - a poverty alleviation strategy. Given that opportunities for unskilled labour exist, real jobs are not sustainable. It may be noted among other reasons that first, there are no training facility components identifiable for local people in such projects, hence the job security is very low. Second, the projects are short-lived, with a duration of between five to ten years. These problems should be compared with the indigenous environmental resource use systems which, when improved upon, have the potential for sustainability, productivity and equity. It is against this background of rapid changes in food needs and the loss of indigenous knowledge and social cohesion, that smallholder farmers and their communities have often lost their self-confidence to adapt, innovate and create. These factors have, among other things, currently contributed to changing food consumption habits locally and at national level, resulting in food shortages, malnutrition and famine. However, like in Melela village, TEKS is now often insufficient to guarantee sustained development on both socio-economic and environmental fronts. Local people's traditional way of life has been threatened.

As for sustainability, the agrotechnological transfers in the SSA should effectively involve the local people as improved smallholder farmers and not as farm labourers and headmen. It should be noted that for the viability of the sector to create employment opportunities under globalisation, programmes for empowering local communities should go hand-in-glove with agricultural investment. Throughout history fertilizers and insecticides have played an essential role in transforming agriculture. As Altieri (1993) notes, massive yield increases have been achieved in both developed and developing countries through chemical applications as the leading tool. The Green Revolution in the South has made at least some countries self-sufficient in food. As liberalisation gains ground, imported machinery, seed, pesticides, fertilizers become unregulated, resulting in dumping of the commodities in developing countries. Evidence from the developing South reveals that pesticide use has generally not been appropriate for subsistence farmers on marginal lands on an economic and ecologic basis (French 2000; German Advisory Council on Global Change 1994). In spite of prohibitively high prices for fertilizers and insecticides, the relatively few smallholders who can afford them are reported to have been tempted to use more and more chemicals, wasting precious capital while simultaneously 
creating environmental pollution. Inability to cope with these technologies is resulting in food insecurity, as observed in Melela village.

Disastrous consequences of the use of these inputs in poor countries of the South include human death and suffering, ever rising costs, increasing farmer dependence on expensive imports, water pollution and damage to biodiversity. To add insult to injury, because too often smallholder farmers are unable to read instructions on chemical containers, chemicals (eg DDT) abandoned in the North for health reasons are still available in the South.

Genetic engineering of seeds is an agrotechnology in industrialised countries which is unfriendly to smallholder farmers and ecologists. For instance, the cultural practice of locally adapted seed varieties and storage systems contributing to reduction in input costs is nullified. Hence the importance of cultural control techniques including botanical pesticides and locally adapted seed varieties currently in use by smallholders cannot be overemphasised (Anderson, et. al. 1996; Rugumamu and Mtumbuka 1998). The potential instability of the artificial agricultural ecosystems in which species diversity has been reduced is thus a subject of concern to biodiversity experts.

Unlike in smallholder production, where most soil nutrients feed crops and livestock products are consumed within the farming community, globalisation propels export-oriented production. The marketing of the produce overseas contributes to soil nutrient exhaustion in the soil system as crops and livestock products are exported. High levels of nutrients involved in this loss include the macronutrients N, P, K (German Advisory Council on Global Change 1994). The situation worsens as production is intensified, yields and nutrient content of the products are increased, all characteristic of western resource exploitation systems. To genuine environmentalists such soil mining practices are unethical (Lal, Miller and Logan 1988). The need for proper environmental impact assessments (EIAs) cannot be overemphasised.

Furthermore, the monitoring activities in the EIA should give concise alternative solutions to issues like socio-economic shocks on the international market. It should be noted that many consumers in the North are increasingly concerned about how their food is produced and are prepared to pay more for products using methods that are environmentally sound.

Because the nature at the end of the investment regime is not spelled out in the investment codes, chances are that the productivity of the 
land at the end of the production season may be lower than at the start. Such a situation is contrary to the principles of sustainable agricultural development and is thus disastrous to the ecology and economy. The above risks would also be coupled with the emergence of environmental refugees who are marginalised by the new industry together with consequent psychosocial, economic and ecological effects besetting them. The EIA statement should, therefore, reveal these disasters holistically as cumulative and interactive compounding over time and space.

\section{Conclusions and Recommendations}

In light of the above findings, it is concluded that economic globalisation processes destabilise smallholder farmers, benefit TNCs, and accelerate the degradation of the environment in SSA. The way out is to empower smallholder farmers so that they are able to take advantage of economic globalisation through planning and management of grassroots based and environment-friendly and profitable production systems of high quality produce. In the light of the above evidence it is clear that economic globalisation processes should be tuned to respond to the material conditions prevailing in the SSA as dictated by the needs of the local people and the carrying capacity of the land. It is axiomatic to conclude that environmental degradation is a function of agricultural land use, the level of technology notwithstanding, but one should quickly add that the problem is deeply rooted in the policy sphere. To this end, development scholars and policy makers are duty bound to take the lead in reforming this situation. It is proposed that democratic opportunities be promoted for enhancing smallholder farmers' and agropastoralists' food self-sufficiency and environmental sustainability using participatory planning. Empowered farmers are more able to take advantage of globalisation through practising environment-friendly agricultural production systems which meet the needs of the farm family, the environment and at the same time production of high value produce for the anonymous market (Agarwal and Narain 1990). In this regard, it may safely be stated that economic globalisation is raising the rewards for countries introducing sound economic governance, but is also raising the costs for economies with poor economic governance. This results in some actors being winners and others losers. We reiterate that a viable approach for achieving economic prosperity and social equity should be based on stakeholders' democratic participation in the design, implementation, monitoring and evaluation of land use plans 
and policies in the SSA (Peatti 1968; Carpenter 1980; PRA 1991; FAO 1993; Boyce 2002).

In principle, to alleviate poverty and conserve the ecosystem calls for the effective participation of local people in planning and management of their natural resources (Bandyopadhyay and Shiva 1989). Capital investment in resources may lead to over-exploitation, negating local progress and creating environmental refugees and land and water deterioration. Such a situation will only accelerate rural poverty tides making many more people poor and the already poor ones poorer than ever before. As initial capital and high yielding technologies are always missing ingredients at the local level, well-tailored joint venture type investments - locals and foreigners - may be a viable solution towards poverty alleviation and resource sustainability.

In order to achieve equity and benefit from globalisation processes there is also the need to reexamine gender divisions of labour and smallholder productivity enhancement requirements within the context of household, subnational, national and international ecological and socioeconomic conditions.

The proposed measures are as follows: (i) regulating liberalisation to meet ecological and smallholder farmers' needs on a sustainable basis. (ii) Access to appropriate productivity enhancing resources, namely farm machinery, fertilizers, seed, insecticides, and efficient cooking stoves. (iii) Access to education, especially regarding the gender division of labour and environmental resources management. Training in appropriate seed, fertilizer and pesticides usage is necessary. Veterinary services must be extended. Sound water and sanitation programmes are vital. Finally, an emphasis on Integrated Management, (IM) should be pivotal.

Through participatory learning approaches, researchers should support the local development process through setting up research with the farmers to investigate problems and opportunities identified by farmers (Rugumamu 1999). Researchers should take part in studies to assess, for example, local institutions and provide advice in setting up a land use planning and management (LUPM) programme. Together with farmers and other stakeholders, researchers should further monitor and evaluate LUPM projects' initiatives in terms of the set programmes and policies. In view of the high cost of research the private sector, the central government and the international organisations as well as the donor 
community are called upon to support this reform initiative in the new millennium.

To this end great attention should be directed to improving TEKS in order to increase environmental resources productivity, improve food security and alleviate rural poverty. It is of paramount importance, however, that agricultural research in the changing socio-economic systems should be an on-going process because specific objectives change. As a technology is developed and used, the production system changes where a new constraint becomes limiting and hence a new technology is to be derived. Achievement of sustainable development and resources productivity should thence be based on methods that democratically integrate men and women as important players in participatory planning of available and potential natural resources management.

There is, therefore, an urgent need now for designing improved yet appropriate environmental resources utilisation technologies to enhance the productivity of the smallholder farmers and their ecosystems given that the major global thrust is to invest in developing countries (French 2000). This goal can only be achieved through a major policy reform at national and international levels to create the conditions for sustainable development at farm level. In this regard democratic global governance based on vibrant civil organisations should be a driving force to bring about new economic globalisation opportunities in SSA in the Third Millennium.

\section{References}

ADALCO, 1990, 'Report of the 3rd Meeting of the Desert and Arid Lands Committee', Ouagadougou, 7-9 February, Nairobi, UNEP.

Adams, P., 1991, Odious Debts: Loose Lending, Corruption and Third World's Environmental Legacy, London: Earthscan.

Agarwal, A., and Narain, S., 1990, 'Village Ecosystem Planning', IIED, Drylands Networks Programme, Paper No.16

Allan, W., 1965, African Husbandman, London, Edinburgh: Intermediate Technology Publications, Oliver and Boyd.

Altieri, M.A. (ed.), 1993, Crop Protection Strategies for Subsistence Farmers, London, Intermediate Technology Publications.

Amin, S., 1976, Unequal Development, New York: Monthly Review Press.

Amin, A.Z., 1986, Country profile, Tanzania, (mimeo), Nairobi, UNEP.

Anderson, M.D., Hollingsworth, C. S., Van Zee, V. Coli, W. M. and Rhodes, M., 1996, 'Consumer Response to Integrated Pest Management and Certification', Agriculture, Ecosystem and Environment Journal, 60: 97-106. 
Bandyopadhyay, J. and V. Shiva, 1989, 'Political Economy of Ecology Movement', Ifda Dossier, 71 , May/June: 37-60.

Barraclough, S. and Finger-Stich, A., 1996, 'Some Ecological and Social Implications of Commercial Shrimp Farming in Asia', Discussion paper, WWF \& UNRISD.

Berry, L., 1971, 'Relief and Physical Features', in Berry. et.al. Tanzania in Maps, University of London Press Ltd, pp 24-27.

Berry, L., and Townshend, J., 1973, 'Soil Conservation Policies in the Semi-arid Regions of Tanzania: A Historical Perspective', in. Rapp, A. et.al. (eds.) Soil Erosion and Sedimentation in Tanzania, Dar es Salaam, BRALUP Research Monograph, No.1: 241-253.

Blaikie, P., 1985, The Political Economy of Soil Erosion in Developing Countries, London, Longmann.

Blaikie, P., 1989, 'Explanation and Policy in Land Degradation and Rehabilitation for Developing Countries', Land Degradation and Rehabilitation, Vol. 1 No. 1, pp. 23-37.

Boyce, J.K., 2002, The Political Economy of the Environment, Cheltenham, Edward Elgar.

Boserup, E. 1965, The Conditions of Agricultural Growth, London, Faber.

Biowman, W.D., 1974, 'Research in natural resources: A review and commentary', Natural Resources Journal, 4, 42-66.

Brown, M. B. and Tiffen, P., 1993, Short Changed: Africa and World Trade, London, Pluto Press.

Carpenter, R.A., 1980, 'Using Ecological Knowledge for Development Planning', Environmental Management, Vol 4, Nol, pp.13-20.

Carson, R., 1962, Silent Spring, Greenwich, Conn, Fawstt Publ. Inc.

Choucri, N., 1998, 'Knowledge Networking for Technology "Leapfrogging”', Cooperation South, UNDP, No. 2, 40-52.

Christiansson, C., 1981, Soil Erosion and Sedimentation in Semi-arid Tanzania. Studies of Environmental Change of Ecological Imbalance, Scandinavian Institute of African Studies. Stockholm, Sweden.

Christiansson, C., 1988, 'Degradation and Rehabilitation of Agropastoral Land: Perspectives on Environmental Changes and Ecological Imbalance', Ambio, Vol. 17, No. 2, pp.44-52.

Chungu, A.S., and Mandara, G.R.R.. 1994. 'The Use of Technology in Alleviating Poverty in Tanzania', in M.S.D. Bagachwa (ed.) Poverty Alleviation in Tanzania: Recent Research Issues, Dar es Salaam University Press (DUP), pp.171-174.

Conacher, A. J., and Dalrymple, J. B., 1977, 'The Nine Unit Landsurface Model: An Approach to Pedogeomorphic Research', Geoderma, Special Issue, No.18.

Cooke, R. U., 1991, 'Common Ground Shared inheritance: Research Imperative for Environmental Geography', Transactions of the Institute of British Geographers, 17: 131-151.

Danish International Development Agency (DANIDA), 1989, Environmental Profile: Tanzania, Danish Foreign Affairs. 
FAO, 1983, 'Guidelines: Land Evaluation for Rainfed Agriculture', Soils Bulletin, No. 53, Rome.

Feierman, S., 1990, Peasant Intellectuals: Anthropology and History in Tanzania, Wisconsin, Madison: The University of Wisconsin Press.

French H, 2000, 'Coping with Ecological Globalisation', in Brown, L.R., Flavian C. and French H. (eds.) The State of the World 2000, New York: W Norton \& Co. Inc.

Frobel, F., Heinrichs, J. and Kreye, O., 1988, The New International Division of Labour: Structural Unemployment in Industrialized Countries and Industrialization in Developing Countries, Cambridge, Cambridge University Press.

GEO-SAREC, 1990, 'Relationship between Land Degradation and Food Security in Tanzania', University of Dar es Salaam (mimeo).

German Advisory Council on Global Change, 1994, World in Transition: The Threat to Soils, Economica Verlag.

Hoffmaister, AW; Pradhan, M.and Samiei H., 1998, 'Have North-South Growth Linkages Changed?', World Development, Vol. 26. No 5, pp.791-808.

Hudson, N, 1987, 'Soil Conservation Practices for the Future', Splash, Vol. 3 No. 3.

Illife, J., 1972, Agricultural Change in Modern Tanganyika, Nairobi, East Africa Publishing House

Jackson, I., 1971, 'Rainfall', in Berry, L. et al (eds.) Tanzania in Maps, London: University of London Press, pp. 36-41.

Juma, C., and Ford D., 1992, 'Facing Africa's Ecological Crisis', in Seidman, A. and Anang. F. (eds.) Twenty First Century Africa: Towards New Vision of Self-Sustainable Development, Trenton, New Jersey: Africa World Press, pp.183-201.

Kennes, W., 1997, 'Developing Countries and Regional Integration', The Courier, No. 165.

Kjekshus, H., 1977, Ecology Control and Economic Development in East African History, London: Heinmann.

Lal, R. Miller, F. P, and Logan, T. J., 1988, 'Are Intensive Agricultural Practices Environmentally and Ethically Sound?', Journal of Agricultural Ethics, 1,193210.

McAuslan, J.P.W.B., 1980, 'A National Environment Agency for Tanzania', UNEP Report.

Morgan, R.P.C., 1986, Soil Erosion and Conservation, London: Longman.

Muller, J., 1980, 'Liquidation or Consolidation of Indigenous Technology', Development Research Series No.1. Aalborg, Uppsala University Press.

Neriove, M., 1988, 'Modernizing Traditional Agriculture', Occasional Papers, No. 6, Washington D.C., International Food Policy Research Institute

Ohiorhenuan, J. F. E., 1998, 'The South in an Era of Globalization', Cooperation South, UNDP, No. 2, 6-15.

Participatory Rural Appraisal (PRA), 1991, World Resources Institute, Washington DC. Clark University, Worster USA and Egerton University, Kenya.

Peatti, L. R., 1968, 'Reflections on Advocacy Planning', American Institute of Planners Journal, 34 (2), 80-88. 
Rapp A., Berry, L. and Temple, P.H., 1973, 'Soil erosion and sedimentation in Tanzania. The Project', in Rap A. et.al. (eds.) Studies of Soil Erosion and Sedimentation. BRALUP Research Monograph, No.1 105-109.

Rocheleau, D.E., 1992, 'Shared Use of Private and Public Property: The Commons Between', (mimeo) Grad. Sch. of Geography. Clark University, Mass.

Rounce, N.V. and Thornton, D., 1939, 'The Ridge in Native Cultivation, with Special Reference to the Mwanza District', A.A.A.I IV: 352-5.

Rodney, W., 1980, How Europe Underdeveloped Africa, New York: Oxford University Press.

Rugumamu, C. P. and Mtumbuka, E., 1998. 'Efficacy of Indigenous Materials to Insect Pests of Household Stored Crops: Strategy for Food Security in Tanzania', Research Report, Sida-Sarec.

Rugumamu, W., 1991, 'Environmental Impact Assessment of Indigenous and Modern Agricultural Technology as a Basis for Technology Policy Design for semiarid Tanzania', IDRC Report.

Rugumamu, W., 1993, 'Outline of an Action Programme to Combat Environmental Degradation and Increase Food and Energy Production in Southern Africa', Desertification Control Bulletin, UNEP, No 22, pp. 69-76.

Rugumamu, W., 1996, 'The State of the Environment in Semi-arid Tanzania: A Strategy Toward Environmentally Sustainable Development', Report Series of UNESCO, No. 13.

Rugumamu, W., 1997, 'The Impact of Gender on Land Productivity in Tanzania', Institute of Southern African Studies, University of Lesotho, GHEC Working Papers, No 13.

Rugumamu, W., 1998, 'The Impact of Agricultural Technology on Sustainable Land Resource Utilization in Africa: The Case of Semi-arid Tanzania', in Ahmed, A. G. and Mlay, W. (eds.) Environment and Sustainable Development in Eastern and Southern Africa: Some Critical Issues, New York: MacMillan Press Ltd \& St. Martins Press Inc, pp.144-160.

Rugumamu, W., 1999, 'Gender Dimension in Relation to Desertification Control Initiatives in the Southern African Community', Desertification Control Bulletin, UNEP, No. 34, pp. 41-47.

Rugumamu, W., 2000, 'Towards a Balanced Village Ecosystem: An Environmentally-sound and Participatory Development Strategy for Semi-arid Tanzania', Sarec Research Report.

Rugumamu, W., 2001, 'Globalisation and Environmental Management', in Ahmed, A.G. et.al. (eds.) Globalisation: Problems and Prospects. New York: MacMillan Press Ltd. \& St. Martins Press.

Ruthenberg, H., 1980, Farming Systems in the Tropics, London, Clareton Press.

Seidman, A. and Anang, F., 1992, (eds.) Towards a New Vision of Self-Sustainable Development, Trenton: Africa World Press Inc.

Shiva, V., 1991, Ecology and the Politics of Survival: Conflicts over Natural Resources in India, Tokyo: United Nations University Press.

Tanzania Livestock Policy, 1986, Dar es Salaam: Government Printers. 
Shivji, G.S. 1998. Not Yet Democracy: Reforming Land Tenure in Tanzania, IIED/ HAKIARDHI/FoL, UDSM.

Smyth A.J., 1972, 'Interpretative Classification of Soil in Land Development', International Geography, 1972, Proceedings 22 International Geographical Congress, University of Toronto Press.

Stebbing, E.P., 1935, 'The encroaching Sahara', Geographical Journal, 85,6; 506-24.

Tanzania National Agricultural Policy. 1983. Dar es Salaam: Government Printers.

The Independent Commission on Population and Quality of Life, 1996, Caring for the Future: A Radical Agenda for Positive Change, Oxford: Oxford University Press.

Timberlake, L., 1985, Africa in Crisis: The Causes, the Cures of Environmental Bankruptcy, London, Earthscan.

UNCTAD, 1995, World Development Report 1995 Transnational Corporations and Competitiveness, New York and Geneva: United Nations.

UNSO, 1986, Assessment of the Problem of Desertification and Review of Ongoing and Proposed Activities to Implement the Plan of Action to Combat Desertification in Tanzania, New York: UNSO.

Van de Welle, E., 1972, 'Implications of Increase in Rural Density', in Ominde, S.H. and Ejiogu. C.N. (eds.) Population Growth and Economic Development, London: Heinemann, pp.117-122.

Van Rensburg, H.J., 1955, 'Runoff and Soil Erosion Test, Mpwapwa, Central Tanganyika', East African Agricultural and Forestry Journal (EAAFJ),Vol. 20, (4), pp. 228-31.

World Commission on Environment and Development, 1987, Our Common Future, New York: Oxford University Press. 
